() Миронов С.П., Цискарашвили А.В., Горбатюк Д.С., 2019

DOI 10.18019/1028-4427-2019-25-4-610-621

\title{
Chronic post-traumatic osteomyelitis as a problem of contemporary traumatology and orthopedics (literature review)
}

\author{
S.P. Mironov, A.V. Tsiskarashvili, D.S. Gorbatiuk
}

National Medical Research Center of Traumatology And Orthopedics n.a. N.N. Priorov, Moscow, Russian Federation

The paper discusses the problem of chronic osteomyelitis from the positions that are either circumvented or not taken into account by practitioners. Microbiological, clinical, pharmacological, pathomorphological and pathophysiological aspects of the inflammatory process of bone tissue are presented. The review also outlines the immunological features of the chronic osteomyelitis course, as well as a contemporary view on this disease as an interdisciplinary problem.

Keywords: chronic osteomyelitis, antibiotic therapy, resistance of microorganisms, inflammation, biochemical cascade, microbial biofilms, bone tissue infectious process, persistent cells, chronic osteomyelitis pathomorphology, osteoblast, osteoclast, Staphylococcus aureus, immunology

\section{INTRODUCTION}

Chronic osteomyelitis is currently considered one of the most severe diseases of the musculoskeletal system. Despite the developments in the medical care [1], the number of patients suffering from osteomyelitis, according to various authors [2, 3], is between 3 and $5 \%$ from the total of patients with bone diseases. Moreover, the disability rate due to it reaches 50 to $90 \%$. The solution to the problem of chronic osteomyelitis requires an interdisciplinary approach and mandatory participation of not only orthopedic and trauma specialist but also clinical pharmacologists, microbiologists, specialists in the field of biochemistry and osteoporosis. In recent years, much information on microbiological, biochemical, immunological studies has been reported in the literature, allowing us to reconsider the usual approaches to the treatment of this disease. Our review of the literature is an attempt to summarize the available data and significantly deepen the understanding of chronic post-traumatic osteomyelitis.

\section{MATERIAL AND METHODS}

Available literature indexed by the PubMed scientific database was reviewed in September October 2018. The search was conducted with the keywords: chronic osteomyelitis, staphylococcus aureus, inflammation, osteoblast, antibiotics, microbiology, immunology, osteoporosis. Those articles were selected that corresponded to the research topic; preference was given to the works published between 2010 and 2018.

If necessary, works published earlier were added to this study, mostly those that discussed the treatments of chronic post-traumatic osteomyelitis that remain unchanged and relevant today.

To clarify the main aspects of the work and obtain additional information, thetargeted search was performed according to the references of the material found. These works were included in the list of references.
Features and essence of chronic post-traumatic osteomyelitis Osteomyelitis as a disease: general clinical information

The infectious process as a whole is defined as an antagonistic interaction of a macroorganism and microorganisms [4]. Close attention to it is explained not only by a continuous evolution of both antagonists, but also by the fact that the emergence and development of new treatment methods involving implantation of systems and devices inevitably brings the issue of microbial colonization. The continuous evolution of both macro- and microorganisms entails the emergence of new clinical and pathogenetic features and forms of the processes already studied. In traumatology and orthopedics, this problem is probably even more urgent than in other areas of medicine due to the need to prevent possible

Mironov S.P., Tsiskarashvili A.V., Gorbatiuk D.S. Chronic post-traumatic osteomyelitis as a problem of contemporary traumatology and orthopedics (literature review). Genij Ortopedii, 2019, vol. 25, no 4, pp. 610-621. DOI 10.18019/1028-4427-2019-25-4-610621. (In Russian) 
infectious complications of such manipulations as osteosynthesis with various fixators, implants made from various artificial materials, bioengineering systems, and implantation of tissue complexes [5].

The term "infection" was introduced into medicine in 1841 by H.W. Hufeland and terminologically denotes a penetration of a pathogen into a macroorganism (contamination), location of the pathogen in the body and the infectious process itself. The latter is characterized by a sequential alternation of a number of stages in the infectious wound state, starting from injury associated with contamination and infection and ending with the restoration of damaged structures. According to a number of authors [6], even in the conditions of a traumatic wound, the microbial flora is an obligatory participant in its cleaning process. However, if there is an imbalance in the quantitative and qualitative composition of the pathogen, on the one hand, and local immunity of the macroorganism, on the other hand, this flora becomes a leading component, sharply slowing down and distorting the course of the processes that run in a traumatic wound [7], and namely:

- inflammation and wound cleansing with the participation of macro- and microphages, T- and B-lymphocytes and other immune defense cells;

- development of granulation tissue and formation of a newly formed microvascular network and the start of the synthesis of extracellular matrix fibroblasts;

- scarring and epithelization (skin wounds).

The incidence of osteomyelitis, according to some authors [9], is $44 \%$ of all purulent and inflammatory diseases of the extremities. The incidence tends to increase due to growth in the number of traffic accidents, military conflicts, disorders of the immune system and the effects of relevant factors (in particular, environmental or viral), changes in the microflora that causes purulent and inflammatory processes (in particular, changes in the spectrum of resistance to antibiotics). Treatment of chronic osteomyelitis should be comprehensive and include the following measures:

1) correct antimicrobial therapy;

2) adequate surgical treatment of wounds (including surgical ones), observance of the principles of asepsis and antiseptics;

3) restoration of blood supply in tissues at risk of purulent inflammatory changes or already affected by them;

4) stable fixation of bone fragments [3].
Chronic osteomyelitis can be considered not only as an independent disease, but also as one of the most serious post-traumatic complications in the treatment of long bone fractures. This is caused not only by a significant number of open fractures with extensive soft tissue damage and concomitant contamination with microorganisms. Thus, open fractures of long bones are complicated by chronic osteomyelitis in $25 \%$ of cases, gunshot fractures in $5.3-27 \%$, and in 1-17\% of cases after osteosynthesis and arthroplasty surgeries (according to some authors' data) [10]. Other studies report that about $7 \%$ of "clean" orthopedic surgeries on bones are complicated by postoperative osteomyelitis [11]. Moreover, if wounds are contaminated (to varying degree), this rate is much higher. Thus, osteomyelitis develops in 21 to $46.2 \%$ of cases after treatment of open fractures of long bones, accompanied by extensive soft tissues damage in the affected segment, and in 7.6 to $13.2 \%$ of cases after open reduction of closed fractures [12].

Alternation of exacerbations and remissions is characteristic for persistent chronic purulent and necrotic process, followed by limb weight-bearing and function disorders. Further on, pathological changes develop not only in the bone but also in soft tissue structures, in other words, in all anatomical and structural elements of the entire limb or its segment.

To date, pathomorphological changes in bone tissue affected by chronic osteomyelitis have been studied quite well. These include ischemic damage due to circulatory disorders, revealed both microand macroscopically. The following features are also characteristic:

- bone necrosis;

- sequestration;

- involvement of soft tissues surrounding the bone in the purulent inflammatory process;

- slowing down and distortion of reparative osteogenesis.

Disability of patients due to chronic osteomyelitis is caused by all of the above changes, which requires the search for new and improvement of existing methods of diagnosis and treatment.

As osteosynthesis with metal structures is one of the methods of contemporary traumatology and orthopedics, the potentiating impact of various implants (in particular, plates, screws, rods) and arthroplasty prostheses should be included in the chronic osteomyelitis risks and its 
rate of development. Wound infection leads to the need to remove metal structures, development of chronic osteomyelitis and permanent disability in $30 \%$ of cases. Treatment is a long, multi-stage and rather difficult process for patients, while the desired clinical result cannot be always achieved [13]. Recently, there has been an increase in the incidence of chronic osteomyelitis and its high recurrence (10-40 \%) 14].

Etiopathogenesis, spectrum of pathogens and epidemiology of chronic post-traumatic osteomyelitis

The purulent process in post-traumatic osteomyelitis is clinically closely associated with impaired macro- and microcirculation in the injured bone tissue, while additional necrosis in the soft tissues that are directly involved in the injured area develops. Thus, it is a kind of "vicious circle", and namely, regional blood circulation and microcirculation in the tissues deteriorate due to the purulent and necrotic process which leads to local tissue ischemia and an increase in the volume of necrotic lesion $[15,16]$.

Patients with chronic post-traumatic osteomyelitis have both morphological deformation of the arteries and depletion of the microvascular bed, a decrease in the number of blood vessels and a decrease in their caliber. The decrease in the intensity of blood supply in the affected segment has been also confirmed with ultrasonic and radionuclide research methods [15]. Further on, vascular stenosis and occlusion develop and significantly complicate the repair processes in the area of infectious process and fracture, delay the consolidation of fragments and, thus, assist in maintaining the infection process and aggravate its treatment [17]. It is believed that the resulting chronic tissue hypoxia causes immunosuppression and, as a consequence, the syndrome of systemic inflammatory response [11, 18, 19]. It results in uncontrolled generalized production of proinflammatory cytokines TNF- $\beta$, IL-1ß, as well as soluble (plasma) cytokine receptors, as well as in an increased spontaneous adhesion of leukocytes to the endothelium and their migration through the endothelial barrier under the influence of pro-inflammatory mediators. Cell adhesion molecules expressed on the endothelium include intercellular adhesion molecules (ICAM-1 and ICAM-2), platelet-endothelial adhesion cell molecules (RECAM-1), vascular cell adhesion molecule (VCAM-1), molecules of the main histocompatibility complex (MHC - main hystocompatibility complex) of class I and II [20, 21, 22].

Currently, the literature data on the epidemiology of chronic post-traumatic osteomyelitis are somewhat limited. The works contain information about the incidence (percentage) of this nosological condition among purulent-inflammatory diseases of the extremities [9] or only bones [3] as part of the musculoskeletal system. Quite generalized data are frequent [23], including on cohorts of patients at risk (in particular, with diabetes mellitus or immunosuppression); however, comprehensive statistics on the incidence have not been provided. Such data are not illustrative enough for planning and organizing the practical medical care, in particular, defining the volumes of care required.

Also, the authors of many works devoted to this topic (including those that served as the basis for writing this review), focus on the spectrum of pathogens of chronic post-traumatic osteomyelitis and their antibiotic resistance, but do not report statistics on their overall incidence.

Hogan et al. [24] provide only general data on the incidence of infectious complications after surgery for open fractures. However, the incidence rates of purulent inflammatory complications, including the nosology condition discussed, depends on the severity of the fracture and ranges from $1 \%$ for conditionally "simple" (small amount of destroyed bone tissue) to $55 \%$ for severe fractures featuring many fragments and massive blood supply damage in the affected bone tissue, which creates suitable conditions for the development of chronic post-traumatic osteomyelitis.

Thus, the epidemiology of chronic post-traumatic osteomyelitis is a subject for further research, in contrast to the microbiological, clinical and other issues of the disease itself. Such medical and statistical parameters as the primary incidence, the incidence of chronic post-traumatic osteomyelitis, and the ratios of the outcomes might be proposed for research in:

- all trauma patients

- patients with open long bone fractures

- patients with trauma of definite segments or anatomical regions, including open fractures

- patients with concomitant, combined and multiple trauma

In the opinion of many authors, the main pathogen of osteomyelitis and purulent arthritis in adults is 
Staphylococcus aureus that is identified in 30 to $75 \%$ of cases; moreover, the subject is one species but not a taxon [27, 28]. Streptococcus agalactiae, Escherichia coli, Haemophilus influenzae, Kingella kingae prevail in pediatric osteomyelitis [27]. It is believed that the dominance of Staphylococcus aureus is explained by a number of expression factors that contribute to its adhesion to the elements of the extracellular matrix. S. aureus produces binding proteins (FNBP, fibronectin-binding protein; CNA, collagen-binding protein and others) that provide fixation (adhesion) of a microorganism on the macroorganism matrix. And this is a mandatory condition for infection process progression [28].

Enterobacter family that includes numerous genera and species frequently causes osteomyelitis (23 \%) [29]. They are Escherichia, Klebsiella, Enterobacter, Citrobacter, Proteus, Providencia, Serratia. Pseudomonas genus and the family of Streptococcae follow; the first in encountered in $9 \%$ of cases and is a hospital infection, while second ones are agents of the infection process in children, but are also identified in adults in $9 \%$ of cases, mainly when a patients with diabetes mellitus contacts with osteomyelitis [30].

Along with $S$. aureus, which domination in the microbiocenosis of the infection focus is indisputable, there is a big portion of coagulase negative staphylococci. The most common are $S$. epidermidis, S. saprophyticus which were isolated in 21.7 and $20.0 \%$ of patients who sustained closed and gunshot fractures of the humerus, respectfully [26].

Hogan et al. [24] provide the following data on the spectrum of pathogens in chronic post-traumatic osteomyelitis that slightly differs in dominant microorganisms composition. The authors present data both for genera and families, and for isolated species of $S$. epidermidis and $S$. aureus, taking into account their resistance or sensitivity to methicillin, which is dictated by the clinical importance of these microorganisms: $S$. epidermidis $\left(M S S E^{1}\right)$ $30 \%$, S. aureus $\left(M S S A^{2}\right)-29 \%, \mathrm{MRSE}^{3}-13 \%$, Enterococcus spp. - $7.0 \%$, MRSA $^{4}-6.0 \%$, Enterobacter - $5.45 \%$, Pseudomonas - $5.0 \%$, and others $-4.6 \%$.

\footnotetext{
${ }^{1}$ MSSE - methicillin-sensitive staphylococcus epidermidis.

${ }^{2}$ MSSA - methicillin-sensitive staphylococcus aureus.

${ }^{3}$ MRSE - methicillin-resistant staphylococcus epidermidis.

${ }^{4}$ MRSA - methicillin-resistant staphylococcus aureus.
}

\section{Pathomorphology of the infection process in bone tissue}

The course of the infectious process in bone tissue is pathogenetically and morphologically close to the infectious process in other tissues, including the wound process. A significant difference between these processes is a primary mechanism of damage to bone and paraosseous tissues. Thus, in wound infection, the trigger is a mechanical injury, and aggravation and severity of the process is determined by a microbial invasion while in osteomyelitis a damaging factor is microbial aggression. The pathogenesis of chronic osteomyelitis is based on a combination of these factors (mechanical injury with impaired microcirculation in the fracture zone and microbial aggression), which exacerbate each other [31]. Until now, the problem of microbial tropism to bone structures in hematogenous osteomyelitis of long and flat skeleton bones has not been fully studied [32].

Participation of osteoblasts in the immune response is an issue of separate importance. The immune role has not historically been attributed to these cells. However, their similar abilities have been currently known. They produce inflammatory cytokines and chemokines in response to infection (as was shown on S. aureus) [33].

It is believed that the etiological pathogens of infection in osteomyelitis (including hematogenous one) are a number of heterogeneous populations and types of bacteria, which suggests that a possible invasion is determined not by generic and species pathogenicity but by disorders in local homeostasis, immunity, microcirculation [34]. So, in the metaphyseal part of long tubular bones at the place of transition of the arterial flow to the venous one, the laminar blood flow it is changed into the turbulent one, which creates favorable conditions for local microbial invasion [35]. A further determining factor in the invasion is a relative depletion of phagocytic cells and the inferiority of the endothelial lining in these parts of the vascular bed, which allows bacteria to invariably translocate into the surrounding tissue [36]. Currently, there is a point of view that the hyperergic response of the immune system can stimulate conditions for further spread of infection [37]. This is realized through a cascade of biochemical mechanisms, starting with the production of pro-inflammatory cytokines (IL-1, IL-6, IL-8 ${ }^{5}$, TNF ${ }^{6}$ ) by monocytes, neutrophils [38] and leading to excessive accumulation of matrix metalloproteinases (MMPs) [39].

${ }^{5} \mathrm{IL}$ - interleukin.

${ }^{6} \mathrm{TNF}$ - tumor necrosis factor. 
These enzymes belong to the family of zincdependent endopeptidases, are synthesized and secreted by a variety of cells, including mesenchymal stromal cells, osteoblasts, fibroblasts, leukocytes, phagocytes. Their main function is modulation of matrix protein metabolism, participation in tissue morphogenesis such as resorption and remodeling, as well as in cell adhesion, differentiation, and proliferation [39]. Under normal conditions, these MMPs are synthesized in small quantities. But if they are hyperproduced, an imbalance of this mechanism develops, resulting in the resorption and degradation of the intercellular matrix. Since an excessive amount of MPP (in particular, MPP-2 and MPP-9, gelatinase-A and gelatinase- $B$, respectively) disrupts reparative histogenesis [40], then the destructive changes in the bone continuously increase with ongoing microbial invasion. A similar role of MPP was described for destruction of cartilage tissue in rheumatoid diseases, where the leading role is played by MPP-1, MPP-8, MPP-13 (other names, respectively: type I collagenase, neutrophil collagenase, stromyelisin-3) [39]. This particular feature can explain the rapid death of hyaline cartilage if the infectious process transits into the joint cavity either in osteomyelitic lesions or primary purulent arthritis.

On the other hand, a decrease in the humoral and cell immunity may be an important factor in pathogenesis what was confirmed by high mortality rates of HIV-infected patients from the complications of musculoskeletal system infections, including infections with atypical microflora [41]. Moreover, some pathogens (primarily $S$. aureus) can cause overproduction of inflammatory cytokines by osteoblasts, altering and potentially distorting the immune response. Such cytokines include IL-6, IL12 , various chemokines, growth factors, as well as CD40 and MHC II molecules (Fig. 1) [42].

Moreover, with immune disorders characteristic for sickle cell anemia, lymphogranulomatosis and other systemic blood diseases, the invasion of atypical salmonella or fungal microorganisms is facilitated. The most frequently detected pathogen, $S$. aureus, has a number of specific properties, in particular, the ability to adhere to elements of the extracellular matrix [28]. Due to overproduction of metalloproteinases, staphylococcus negatively affects both the matrix and cell elements of bone tissue, activating various mechanisms of differentiation and activation of osteoclasts, inhibiting proliferation and causing apoptotic death of osteoblasts, resulting in progressive osteolysis, destruction of bone tissue, what contributes to further invasion and reproduction of the microorganism. The spectrum of $S$. aureus destructive action on osteoblasts is due to the following mechanisms:

- decrease in proliferation of osteoblasts

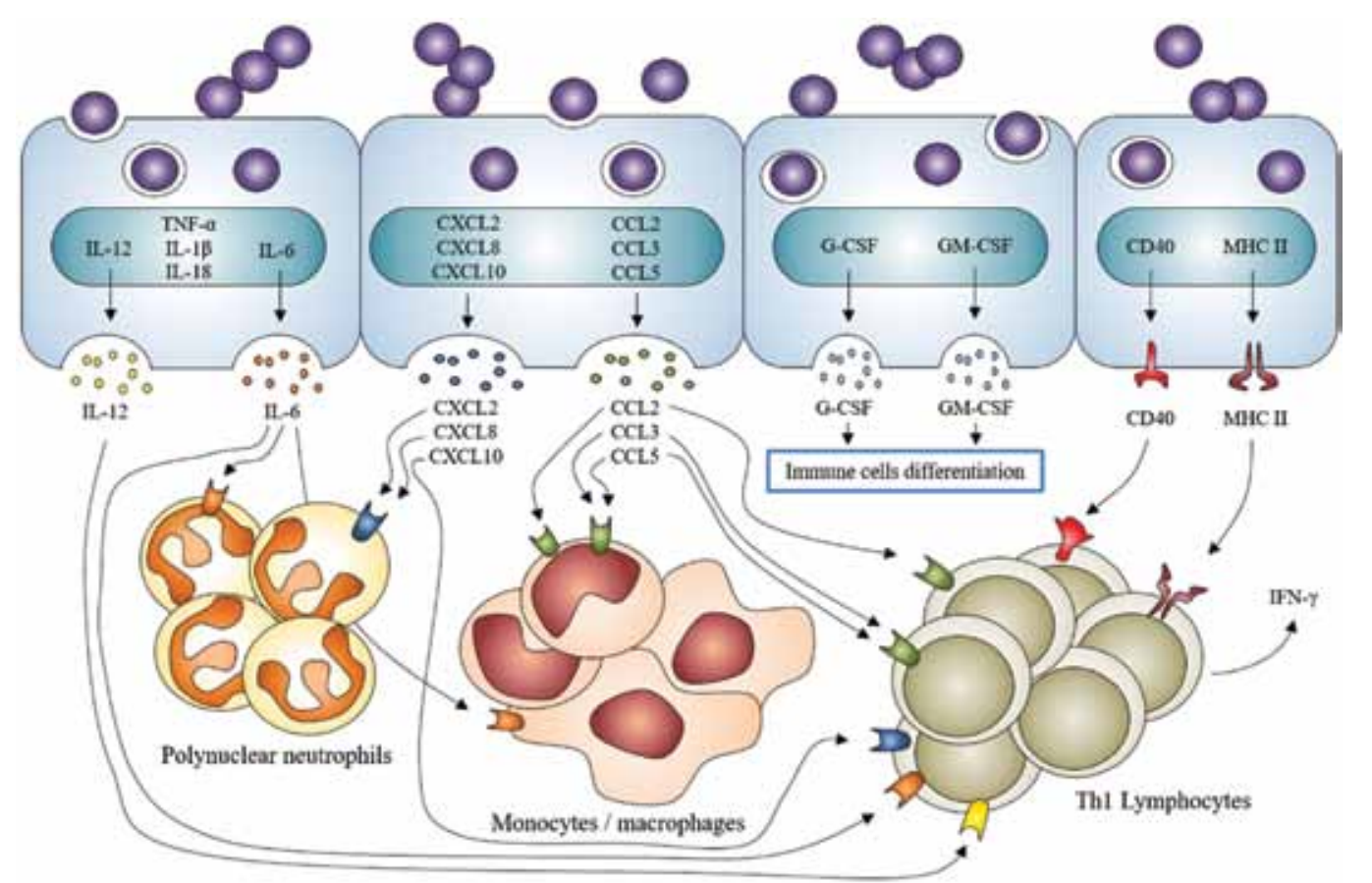

Fig. 1 A variety of cascades of inflammatory responses triggered by $S$. aureus in interaction with osteoblasts. IL - interleukins; CXCL, CCL - chemokines; G-CSF, GM-CSF - growth factors. Additionally, there develops activation and growth in the number of macrophages, which are also "targets" for $S$. aureus [42] 
- decrease in the production of enzymes (laboratory tests show a decreased level of alkaline phosphatase) and of extracellular matrix components such as type 1 collagen, osteocalcin, osteopontin, osteonectin (data were obtained on models of osteoblast infection with S. aureus in vitro) [42].

Disorder of bone mineralization: in cultures of $S$. aureus-infected osteoblasts, mineralization ran in smaller volumes than in the control group [43].

A group of authors showed that S. aureus cells that were killed by ultraviolet radiation located on the surface of a titanium implant improved the adhesion of osteoblasts, as well as their differentiation and bone mineralization, which cast doubt of the only $S$. aureus impact on these cells. Jin et al. suggested that such an effect of $S$. aureus on osteoblasts is mediated by miRNAs [43]. Understanding the exact mechanism of this phenomenon might be the subject of further research. First of all, the relevant question is which factors inhibit and which stimulate the activity of osteoblasts.

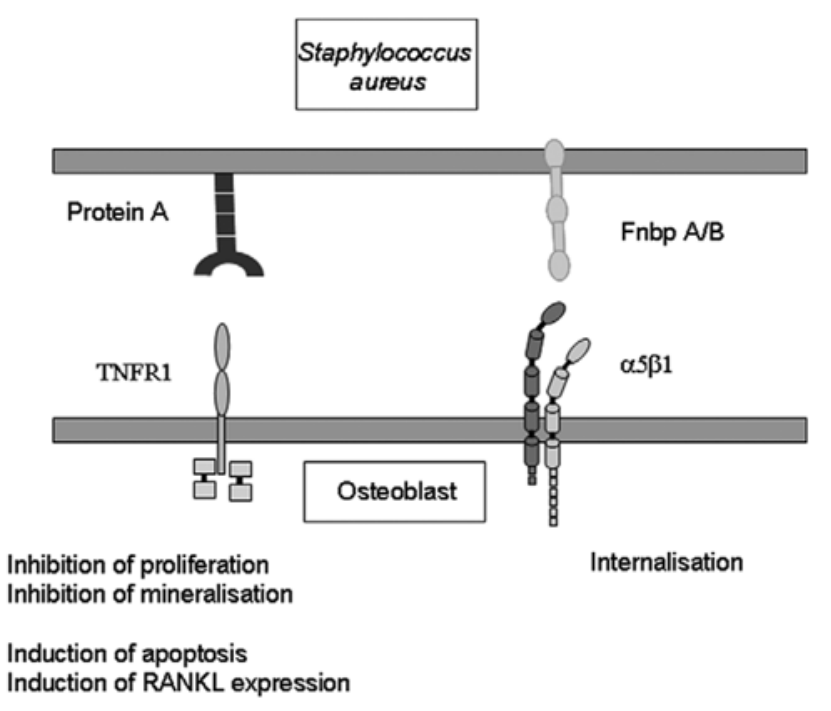

Fig. 2 Molecular factors of S.aureus involved in interaction with osteoblasts [35]. The pathogen protein A directly binds to the TNFR-1 receptor of osteoblasts thus activating a cascade of cell reactions that result in apoptosis. Fnbp A/B (fibronectin-binding proteins) are a kind of "anchors" that interact with integrin a5b1. It was shown that adhesion of $S$. aureus proceeds extremely slowly in the absence of Fnbp A/B. In addition to these mechanisms, $S$. aureus increases the expression of RANKL ligands, which leads to increased bone resorption by osteoclasts and its destruction; the mechanism of this interaction has been currently studied

Invasion of $S$. aureus into osteoblasts is mediated by the binding of the pathogen to the corresponding proteins on the surface of the latter (Fig. 2). Absorbed bacteria "slip" into the cytoplasm of the cell and present a rather difficult "target" for the immune system, further causing apoptosis of the cell. The fact is that this mechanism works only on living cells. In the experiment, the pathogen did not invade the osteoblasts killed [45]. It is believed that the ability of $S$. aureus to induce apoptosis of osteoblasts does not depend on the degree of their activity suppression. Data in favor of this fact were obtained by authors who studied in vitro the process of infection of osteoblasts with this pathogen [46]. In osteoblasts infected with $S$. aureus, apoptosis is triggered by the TRAIL ligand (tumor necrosis factor-related apoptosis-inducing ligand). The specified ligand interacts with the "death receptors" DR4 and DR5, expressed in $S$. aureus-infected osteoblasts, thus activating apoptotic signaling pathways, in particular caspase- 8 and caspase- 9 ; caspase- 3 is activated as one of the final "chain links" (Fig. 3).

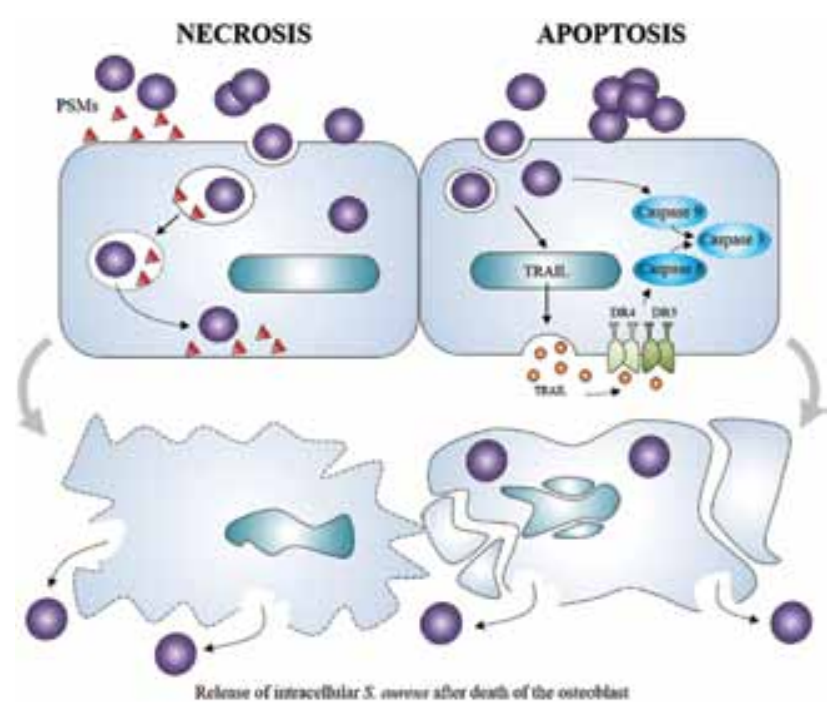

Fig. 3 Induction of osteoblast cell death after being infected with S. aureus; necrosis (left) and apoptosis (right). After the death of the osteoblast, S. aureus enters the intercellular matrix and is capable to infect other osteoblasts [42]

In addition to the apoptotic one, a necrotic pathway of osteoblast death is also possible, in which the key factors are the toxins produced by $S$. aureus, PSM $\alpha$ and PSM $\beta$ (PSMs), as well as the $\delta$-toxin and $\alpha$-toxin [47]. These factors do not involve signaling cascades, but directly damage the osteoblast membrane. Thus, the two pathways of osteoblast death in S. aureus infection proceed independently of each other.

A clinically significant and noteworthy feature of S. aureus is its ability to influence osteoclastogenesis. Through this mechanism, the pathogen is able to further destroy bone tissue. The mechanism consists of two main biochemical effects: osteoblast, infected with $S$. aureus, 
not only increases the synthesis of the RANK-L and sRANK-L ligand (soluble form of the indicated ligand) but also reduces the production of osteoprotegerin (OPG), since the synthesis of microRNA, modulating production of this factor, is disrupted. Thus, $S$. aureus indirectly enhances osteoclastogenesis by interacting with osteoblasts. Also, prostaglandin E2 (PGE2), synthesized in large quantities by $S$. aureus-infected osteoblasts, acts as an auto- and paracrine factor that increases RANK-L production [48]. This prostaglandin binds to receptor EP4 of osteoblast, which leads to additional synthesis of RANK-L ligands [50] (Fig. 4).

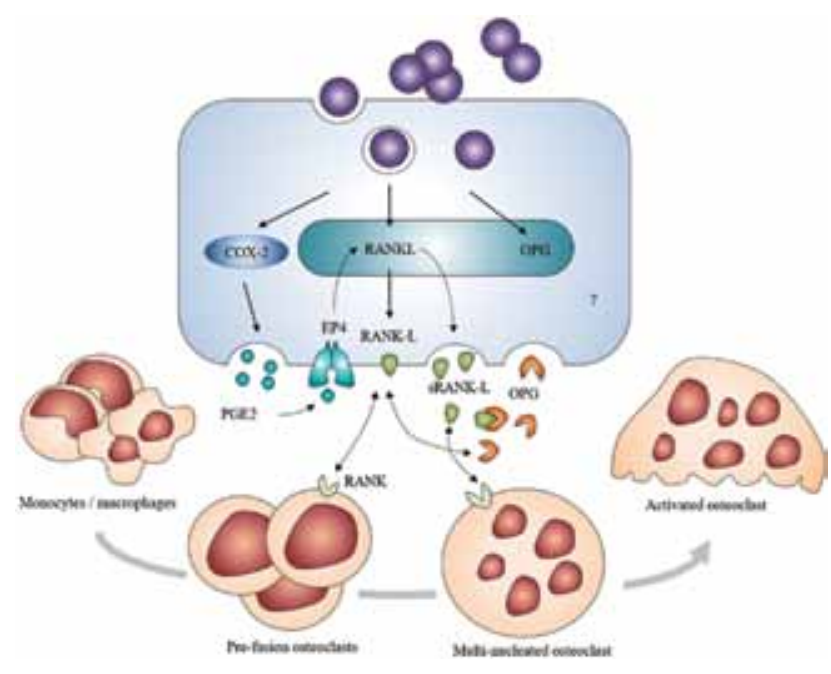

Fig. 4 Stimulation of osteoclastogenesis by factors synthesized by osteoblast infected with $S$. aureus. COX-2 - cyclooxygenase-2. By activating several biochemical pathways, $S$. aureus stimulates the differentiation of monocytes and macrophages into

"mature" osteoclasts thus enhancing bone resorption [42]

It should be noted that adhesion to osteoblasts is not an exceptional feature of $S$. aureus. A similar mechanism is also possessed by the family of enterobacteria that use type IV pili, type I fimbriae, surface protein groups - the so-called selfassociating autotransporters, SAAT) [50]. They are able to increase the production of effector proteins with specific cytotoxic actions, endotoxins, upon adhesion, which also contributes to the development of the infectious focus and progression of the osteomyelitis process. In addition to these pathogens, such a mechanism is present in the genus Pseudomonas and the family of Streptococcae [31].

The ability of several pathogens not only to resist phagocytosis, but also to survive in a phagocytosed state is very important. This factor explains the frequency of chronicity of the osteomyelitis process. Thus, Staphylococcus aureus is able to persist in macrophages and osteoblasts. Thereby, production of intracellular activated oxygen species decreases, alkaline phosphatase activity in osteoblasts decreases, and the phagocytic activity of macrophages increases compared to uninfected cells. The mechanisms of protection of Staphylococcus aureus with phagocytosis by its macrophage are presented in Fig. 5 .

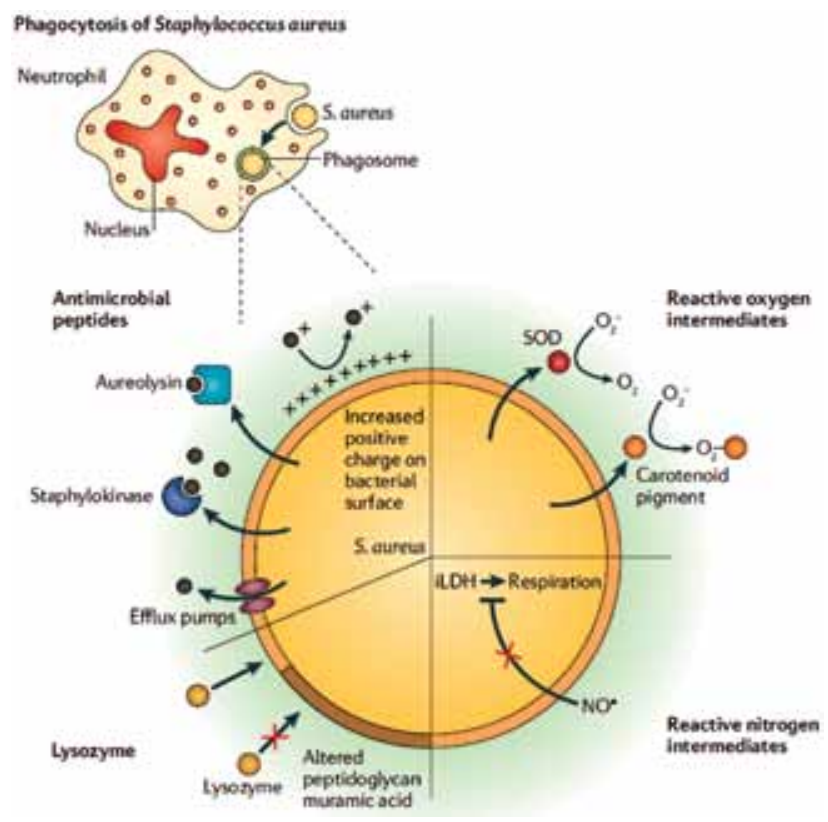

Fig. 5 Protection mechanisms of $S$. aureus in phagocytosis [51]. Top left: illustration of the phagocytosis process of $S$. aureus by a macrophage. Bottom right: protection mechanisms. Areolysinblocks the macrophage antimicrobial peptides, which are also repelled by the positively charged membrane of the pathogen, and once penetrated through the cell wall are removed by molecular pumps (efflux pumps). Lysozyme, produced by the macrophage, is unable to interact with the cell wall of $S$. aureus, which contains muramic acid. $S$. aureus also blocks the macrophage carotenoid pigment due to the secretion of superoxide dismutases (SOD), which prevent the formation of activated oxygen species hazardous to the pathogen. Finally, due to the secretion of inducible lactate dehydrogenase (iLDH) $S$. aureus is insensitive to the effects of the so-called active nitrogen compounds (reactive nitrogen intermediates), the function of which is to block the cellular respiration of the bacterial cell. Thus, the respiratory process continues

A similar ability of $S$. aureus to infect not only osteoblasts, but also epithelial, endothelial cells and leukocytes has been confirmed by available data [52]. Such mechanisms are also characteristic of other pathogens, and in some cases they have an antiapoptotic effect on the macrophage. Edwardsiella tarda possesses such properties. In other cases, on the contrary, infection of a macrophage leads to a rapid death of the latter, which is typical for S. typhimurium.

Biofilms and their impact on therapy and the course of purulent inflammatory complications

It is widely known that the development of chronic osteomyelitis is inextricably linked with the formation 
of biofilms that protect microorganisms both from the immune response of the host organism and from the effects of antibiotics. It significantly complicates the task of treating the purulent inflammatory process. A biofilm is a form of adaptation for bacteria to changing environmental conditions (the second form is their existence as separate cells). Bacterial cells in biofilms are surrounded by an exopolysaccharide matrix that also contains exogenous substances which are peptide and protein molecules, salts, extracellular DNA. Biofilms can be formed both by virulent microorganisms (Staphylococcus aureus) and conditionally pathogenic (opportunistic), such as Staphylococcus epidermidis [53]. Bacteria in the form of separate cells ("planktonic" form or planktonic cells) are exposed to immune agents and antibiotics, while the biofilm, as mentioned above, levels the effect of these factors [54]. In particular, the sensitivity of bacteria in biofilms to antibiotics is 100 to 1000 times lower than that of planktonic forms, which requires an increase in the concentration of antibiotics by a comparable number of times [55]. Because of this, laboratory methods for detecting the sensitivity of bacteria to antibiotics cannot be applied, since the data obtained do not correspond to the results of therapy.

Main phases of biofilm formations have been studied well:

1. Reversible attachment (adhesion) to the surface. "Planktonic" cells that are free floating tend to adhere to the surface to form a biofilm. The surface is a wound surface (soft tissue or bone tissue), as well as any medical implant and devices. Among the mechanisms involved in this process are electrostatic, hydrophobic, Van der Waals forces.

2. Irreversible (permanent) adhesion to the surface. The bacteria are not only "fixed" on the surface at this phase but the exchange of genes and the differentiation of bacteria are initiated, which ensures that their survival continues.

\section{Formation of a mucous protective matrix.} The composition of the matrix mucus may vary, but its main components are polysaccharides, proteins, glycolipids and bacterial DNA. Subsequently, planktonic bacteria, microcolonies and fragments of the biofilm itself constantly separate from the biofilms, disperse and form new colonies.

Chronology of biofilm formation is characterized by a similar course:

1) adhesion occurs within a few minutes;
2) microcolonies firmly attached to the substrate are created within 2-4 hours;

3) production of extracellular polysaccharides (matrix formation) takes 6-12 hours;

4) the biofilm finally forms within 2-4 days;

5) recovery of the biofilm after mechanical failure occurs within 24 hours.

As already mentioned, bacteria in biofilms are less sensitive not only to antibiotics, but also to the immune response from the macroorganism. The situation is aggravated by the fact that the phagocytes of the macroorganism not only experience difficulties in killing bacteria in the biofilm, but also undergo inactivation themselves.

The process of biofilm formation can be divided into two main phases: primary (reversible) adhesion of bacteria to a substrate (endoprosthesis or metal) and secondary (irreversible) adhesion. It was found that the use of antibiotics (linezolid, vancomycin, daptomycin) in minimal inhibitory concentrations $\left(\mathrm{MIC}^{7}\right)$ can prevent the phase of primary adhesion. When compared, antibiotics added to the biofilm already formed, i.e. in the second phase, did not have effect even at antibiotic concentrations that were 100 times higher than MIC [56].

However, Stewart and other authors [57] reported that certain types of antibiotics can penetrate biofilms, despite the fact that their concentration inside the biofilm is in any case much lower than in the surrounding solution. So, it was shown that daptomycin molecules, detected using a fluorescent labelling, can penetrate the biofilm formed by $S$. epidermidis with a diffusion coefficient of about $28 \%$. Vancomycin and rifampicin, according to these authors, are able to "overcome" the artificial biofilm formed by staphylococci, in therapeutic concentrations. Similar findings were obtained in in vitro experiments for vancomycin [58]. Thus, the point that the biofilm matrix is a purely mechanical obstacle for antibiotic molecules was doubted. However, no significant death of bacterial cells in the biofilm was detected, despite the fact that antibiotics penetrated in effective (therapeutic) concentrations [59]. Therefore, the effect of biofilms is more likely inactivates antibiotics than creates a mechanical barrier for them.

A number of researchers believe that the use of antibiotic combinations instead of isolated drugs can be a way out, especially in the early stages of adhesion,

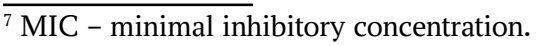


when it is still reversible. Parra-Ruiz et al. showed using the pharmacokinetic-pharmacodynamic model (pharmacokinetic / pharmacodynamic model, PK / PD) that neither moxifloxacin at a dose of $400 \mathrm{mg}$ every 24 hours nor daptomycin in high doses $(10 \mathrm{mg} / \mathrm{kg}$ every 24 hours) did not significantly influence on the growth of biofilms; however, when these drugs are combined, the bactericidal effect was observed or sharply increased [60]. The results of another study [61], in which similar observations were made for the combination of Telavancin with the such drugs as vancomycin, teicoplanin, linezolid and moxifloxacin, are also consistent with the findings obtained. Moxifloxacin, according to the above findings, is the most effective (according to the bactericidal effect) drug, provided that it is used in combination with others. It is also advisable to use combinations of drugs such as clarithromycin + cefazolin or vancomycin; linezolid + daptomycin, as well as combinations of rifampicin with linezolid, cefazolin, oxacillin, vancomycin, gentamicin, azithromycin, ciprofloxacin, fusidic acid (for treatment of biofilms formed by bacteria of the genus Staphylococcus). Thus, the only effective option for antibiotic therapy of biofilms is the use of drug combinations.

Currently, there are data from a number of in vivo studies on laboratory animals. Thus, one study
[62] reflects the results of MRSA-implant-associated infection treatment with combinations of rifampicin with linezolid and vancomycin. None of the antibiotics gave a positive clinical effect when used separately; however, the combination of the drugs prescribed four weeks after the infection onset for 21 days was successful. Saleh-Mghir and colleagues obtained a similar result on rabbits when combined rifampicin + vancomycin + daptomycin [63].

Biofilms are characterized by the presence of the so-called persistent cells which are metabolically inactive cells that ensure the survival of the population under the conditions that would be lethal to most cells in a biofilm [64]. The number of such cells does not exceed $1-5 \%$ of the total cell mass; it increases mainly in the stationary phase. Such cells become antibiotictolerant due to a sharp slowdown in all physiological and biochemical processes of the cell on which antibiotics can have an impact. This mechanism should not be confused with antibiotic resistance mediated by a change in the "targets" of antibiotics, the synthesis of neutralizing enzymes, etc. Moreover, it is known that bactericidal antibiotics predominantly act on actively dividing cells; in regard to persisters, most proteins of which temporarily stop working, these drugs would have only a bacteriostatic effect [65].

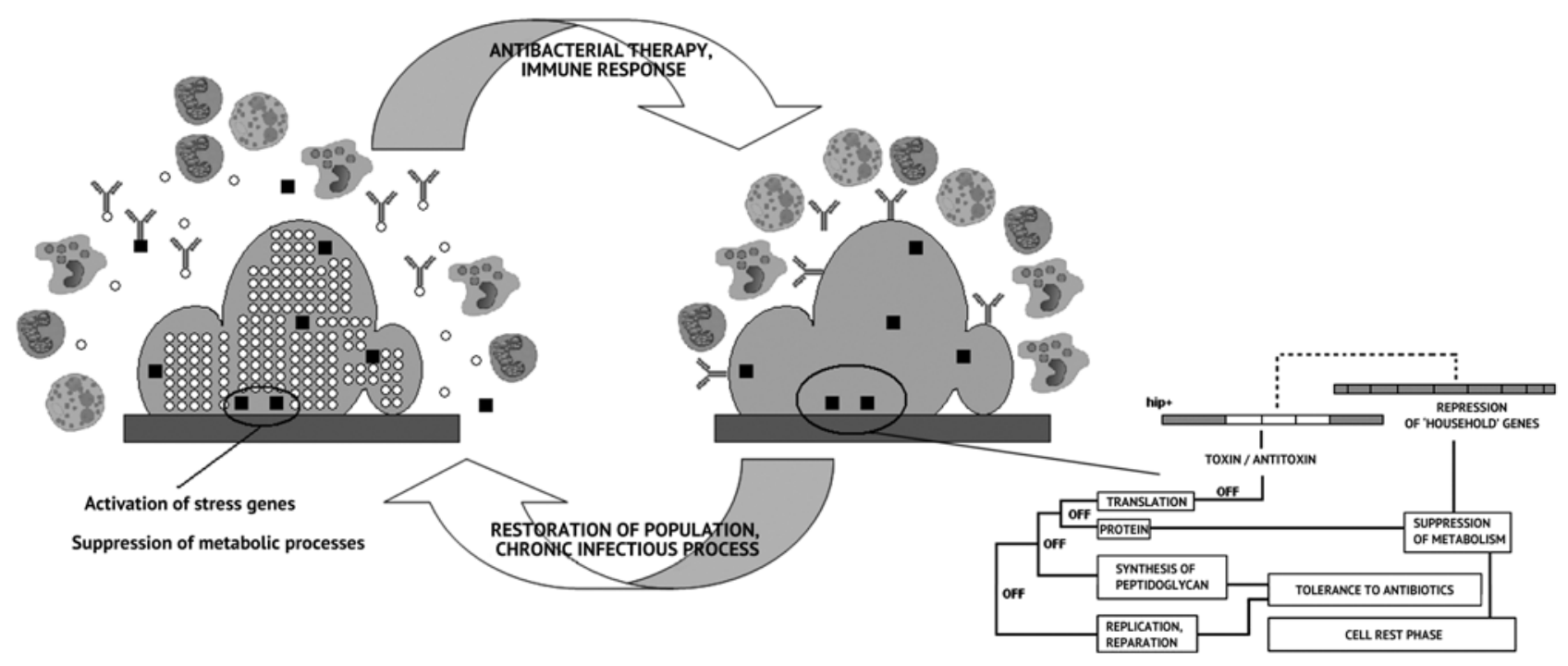

Fig. 6 Mechanism of bacterial population persistence (white dots) based on persister cells (black squares) due to their reduced metabolism. Diagram of Gostev et al. [66] based on the drawing from the book Biofilms, Infection, and Antimicrobial Therapy edited by John L. Pace et. al., 2006 (p. 245, Fig. 12.3)

\section{CONCLUSION}

Chronic post-traumatic osteomyelitis still "classical" methods existing in purulent surgery and remains a significant problem in traumatology and orthopedics. Due to the characteristic features of the bone tissue infectious process, treatment with traumatology is insufficient. The microorganisms that cause chronic osteomyelitis have an "arsenal" of means for protection and preservation of their 
population, while various processes of bone tissue destruction proceed simultaneously, exacerbating each other. So, the "proper" infection process with purulent inflammatory reactions is associated with an increase in bone resorption and developing resistance to all new antimicrobial agents as well as progression of pathogen populations which are biological communities formed into biofilms, along with bone matrix destruction under the action of metalloproteinases of the immune system.

To solve this problem, an interdisciplinary approach is required with the participation and cooperation of not only traumatologists and orthopedic surgeons but also immunologists, microbiologists, clinical pharmacologists, as well as researchers in basic science, in particular, cytology and biochemistry, pharmacological chemistry, materials science and others. Promising research topics are the search and synthesis of new antibacterial drugs, improvement of surgical debridement methods, development and improvement of the methods to combat biofilms (physical, mechanical, medicinal and other), blocking the pathological (perverted) immune and osteoresorbable reactions, and also the search, development and improvement of the methods preventing chronic post-traumatic osteomyelitis in patients both prior to the injury and during its initial surgical treatment.

Funding and conflict of interest The authors did not receive funding for this work. There is no conflict of interest.

\section{REFERENCES}

1. Ishutov I., Alekseev D. Osnovnye printsipy ozonoterapii v lechenii patsientov s khronicheskim osteomielitom [The main principles of ozonotherapy in the treatment of patients with chronic osteomyelitis]. Vestnik Eksperimentalnoi i Klinicheskoi Khirurgii. 2011, vol. 4, no. 2, pp. 314-320. (in Russian)

2. Eid A.J., Berbari E.F. Osteomyelitis: review of pathophysiology, diagnostic modalities and therapeutic options. J. Med. Liban., 2012, vol. 60 , no. 1 , pp. 51-60.

3. Kuznetsov N.A., Nikitin V.G., Teleshova E.B., Milchakov A.A. Antiseptiki i biodegradiruiushchie implantaty v lechenii khronicheskogo posleoperatsionnogo osteomielita [Antiseptics and biodegrading implants in the treatment of chronic postoperative osteomyeitis]. Khirurgiia. Zhurnal im. N.I. Pirogova, 2009, no. 5, pp. 31-35. (in Russian)

4. Calhoun J.H., Manring M.M., Shirtliff M. Osteomyelitis of the long bones. Semin. Plast. Surg., 2009, vol. 23, no. 2, pp. 59-72. DOI: $10.1055 / \mathrm{s}-0029-1214158$.

5. Rakhmanova A.G., Neverov V.A., Prigozhina V.K. Infektsionnye bolezni. rukovodstvo. 2-e izd. [Infectious Diseases. Manual. 2nd Ed.]. SPb., Piter, 2001, 569 p. (in Russian)

6. Gatina E.B., Mitronin M.I., Akhtiamov I.F., Ziatdinov B.G., Kilmetov T.A., Eremin I.K. Infektsionnye oslozhneniia kak pokazatel smeny variantov lecheniia $v$ travmatologii $i$ ortopedii [Infectious complications as an indicator of changing treatment options in traumatology and orthopaedics]. Prakticheskaia Meditsina, 2013, vol. 2, no. 1-2 (69), pp. 34-36. (in Russian)

7. Kuzina M.I., Kostiuchenok B.M., eds. Rany i ranevaia infektsiia: rukovodstvo dlia vrachei [Wounds and wound infection: guide for physicians]. M., Meditsina, 1990, 592 p. (in Russian)

8. GuoS.,DipietroL.A. Factorsaffecting woundhealing. J.Dent.Res.,2010,vol.89, no.3,pp. 219-229. DOI:10.1177/0022034509359125.

9. Amiraslanov Iu.A., Svetukhin A.M., Borisov I.V. Sovremennye printsipy khirurgicheskogo lecheniia khronicheskogo osteomielita (lektsiia) [Modern principles of surgical treatmenmt of chronic osteomyelitis (lecture)]. Infektsii v Khirurgii, 2004, vol. 2, no. 1, pp. 8-13. (in Russian)

10.Brause B. Infections with prostheses in bones and joints. In: Mandell G.L., Bennett J.E., Dolin R., eds. Mandell, Douglas, and Bennett's Principles and Practice of Infectious Diseases. $7^{\text {th }}$ Ed. Philadelphia, Churchill Livingstone, Elsevier, 2010, vol. 1, part II, section K, pp. 1469.

11.Rak A.V., Nikitin G.D., Linnik S.A., Khaimin V.V., Kravtsov D.V., Romashov P.P., Zhdanova V.I. Khronicheskii osteomielit i ego lechenie [Chronic osteomyelitis and its treatment]. VII Sezd travmatologov-ortopedov Rossii: tez. dokl. [Proc. VII Congress of traumatologists-orthopedists of Russia]. Novosibirsk, 2002, vol. 1, pp. 355-356. (in Russian)

12.Khatod M., Botte M.J., Hoyt D.B., Meyer R.S., Smith J.M., Akeson W.H. Outcomes in open tibia fractures: relationship between delay in treatment and infection. J. Trauma, 2003, vol. 55, no. 5, pp. 949-954. DOI: 10.1097/01.TA.0000092685.80435.63.

13.Gubin A.V., Kliushin N.M., Korkin A.A., Koiushkov A.N. Ispolzovanie chreskostnogo osteosinteza v lechenii khronicheskogo osteomielita u detei [Transosseous osteosynthesis use in the treatment of chronic osteomyelitis in children]. Ilizarovskie Chteniia: materialy vseros. nauch.-prakt. konf. s mezhdunar. uchastiem "Aktualnye Voprosy Travmatologii i Ortopedii Detskogo Vozrasta" [Ilizarov Readings: materials of the All-Russian Scientific-practical Conference with international participation "Relevant Problems of Pediatric Traumstology and Orthopaedics”]. Kurgan, 2013, pp. 54-55. (in Russian)

14.Kumar J., Ramachandran M., Little D., Zenios M. Pelvic osteomyelitis in children. J. Pediatr. Orthop. B, 2010, vol. 19, no. 1, pp. 38-41. DOI: 10.1097/BPB.0b013e328332f4b5.

15.Slobodskoi A.B., Osintsev E.Iu. Dopolnitelnye vozmozhnosti uluchsheniia krovoobrashcheniia pri khronicheskom posttravmaticheskom osteomielite [An additional potential of circulation improvement for chronic posttraumatic osteomyelitis]. Novye Tekhnologii v Meditsine: tez. nauch.-prakt. konf. [Proc. Scientific-practical Conference "New Technologies in Medicine”]. Kurgan, 2000, part 2, pp. 57-58. (in Russian) 
16.Gelfand B.R., Iakovlev S.V., Iaroshetskii A.I., Protsenko D.N., Romanovskii Iu.Ia. Primenenie aktivirovannogo proteina C v lechenii bolnykh s tiazhelym sepsisom [The use of activated protein $\mathrm{C}$ in the treatment of patients with severe sepsis]. Infektsii $v$ Khirurgii, 2004, vol. 2, no. 1, pp. 20-27. (in Russian)

17.Pereslytskikh P.F. Patogenez gematogennogo i posttravmaticheskogo osteomielita (eksperimentalno-teoreticheskie aspekty) [Pathogenesis of hematogenous and posttraumatic osteomyelitis (Experimental and theoretical aspects]. Irkutsk, 2002,122 p. (in Russian)

18.Eriukhin I.A., Shliapnikov S.A. Ekstremalnoe sostoianiie organizma: elementy teorii i prakticheskie problemy na klinicheskoi modeli tiazheloi sochetannoi travmy [Organism's extreme condition: elements of theory and practical problems in the clinical model of severe concomitant injury]. SPb., Eskulap, 1997, 288 p. (in Russian)

19.Guchev I.A., Klochkov O.I. Antibakterialnaia terapiia netiazheloi vnebolnichnoi pnevmonii [Antibacterial therapy of non-severe community-acquired pneumonia]. Voenno-meditsinskii Zhurnal, 2003, no. 11, pp. 19-24. (in Russian)

20.Totolian A.A., Freidlin I.S. Kletki immunnoi sistemy [Cells of the immune system]. SPb., 2000, vol. 1-2, 231 p. (in Russian)

21.Bull D.J., Serrano N., Zito F., Jones L., Montgomery H.E., Rumley A., Sharma P., Lowe G.D., World M.J., Humphries S.E., Hingorani A.D. Human CRP gene polymorphism Influences CRP levels: implications for the prediction and pathogenesis of coronary heart disease. Arterioscler. Thromb. Vasc. Biol., 2003, vol. 23, no. 11, pp. 2063-2069. DOI: 10.1161/01.ATV.0000084640.21712.9C.

22.Verstrepen L., Bekaert T., Chau T.L., Tavernier J., Chariot A., Beyaert R. TLR-4, IL-1R and TNF-R signaling to NF-kappaB: variations on a common theme. Cell. Mol. Life Sci., 2008, vol. 65, no. 19, pp. 2964-2978. DOI: 10.1007/s00018-008-8064-8.

23.Taki H., Krkovic M., Moore E., Abood A., Norrish A. Chronic long bone osteomyelitis: diagnosis, management and current trends. Br. J. Hosp. Med. (Lond), 2016, vol. 77, no. 10, pp. C.161-C164. DOI: 10.12968/hmed.2016.77.10.C161.

24.Hogan A., Heppert V.G., Suda A.J. Osteomyelitis. Arch. Orthop. Trauma Surg., 2013, vol. 133, no. 9, pp. 1183-1196. DOI: 10.1007/ s00402-013-1785-7.

25.Diémé Ch., Sarr L., Guèye A.B., Coulibaly N.F., Sané A., Ndiaye A., Sèye S. Therapeutic aspects of chronic bone infections and management challenges. Open Journal of Orthopaedics, 2014, vol. 4, pp. 21-26. URL: http://www.scirp.org/journal/ojo; http:// dx.doi.org/10.4236/ojo.2014.42004.

26.Kliushin N.M., Naumenko Z.S., Rozova L.V., Leonchuk D.S. Mikroflora khronicheskogo osteomielita plechevoi kosti [Microflora of chronic humeral osteomyelitis]. Genij Ortopedii, 2014, no. 3, pp. 57-59. (in Russian)

27.Vander Have K.L., Karmazyn B., Verma M., Caird M.S., Hensinger R.N., Farley F.A., Lubicky J.P. Community-associated methicillin-resistant Staphylococcus aureus in acute musculoskeletal infection in children: a game changer. J. Pediatr. Orthop., 2009, vol. 29, no. 8, pp. 927-931. DOI: 10.1097/BPO.0b013e3181bd1e0c.

28.Flock J.I. Extracellular-matrix-binding proteins as targets for the prevention of Staphylococcus aureus infections. Mol. Med. Today, 1999, vol. 5, no. 12, pp. 532-537.

29.Allison D.C., Holtom P.D., Patzakis M.J., Zalavras C.G. Microbiology of bone and joint infections in injecting drug abusers. Clin. Orthop. Relat. Res., 2010, vol. 468, no. 8, pp. 2107-2112. DOI: 10.1007/s11999-010-1271-2.

30.Conrad D.A. Acute hematogenous osteomyelitis. Pediatr. Rev., 2010, vol. 31, no. 11, pp. 464-471. DOI: 10.1542/pir.31-11-464.

31.Dziuba G.G. Ortopedicheskaia khirurgiia osteomieliticheskikh koksitov. Avtoref. Diss. dokt. med. nauk [Orthopedic surgery of osteomyelitic coxites. Synopsis Dr. med. sci. diss.]. Novosibirsk, 2017. 44 s. (in Russian)

32.Ribeiro M., Monteiro F.J., Ferraz M.P. Infection of orthopedic implants with emphasis on bacterial adhesion process and techniques used in studying bacterial-material interactions. Biomatter., 2012, vol. 2, no. 4, pp. 176-194. DOI: 10.4161/biom.22905.

33.Wright K.M., Friedland J.S. Differential regulation of chemokine secretion in tuberculous and staphylococcal osteomyelitis. J. Bone Miner. Res., 2002, vol. 17, no. 9, pp. 1680-1690. DOI: 10.1359/jbmr.2002.17.9.1680.

34.Termaat M.F., Raijmakers P.G., Scholten H.J., Bakker F.C., Patka P., Haarman H.J. The accuracy of diagnostic imaging for the assessment of chronic osteomyelitis: a systematic review and meta-analysis. J. Bone Joint Surg. Am., 2005, vol. 87, no. 11, pp. 24642471. DOI: 10.2106/JBJS.D.02691.

35.Jansson A., Jansson V., von Liebe A. Pediatric osteomyelitis. Orthopade, 2009, vol. 38, no. 3, pp. 283-294. DOI: 10.1007/s00132008-1402-6.

36.Mader J., Calhoun J. Osteomyelitis. In: Mandell G.L., Bennett J.E., Dolin R., eds. Mandell, Douglas and Bennett's Principles and Practice of Infectious Diseases. $5^{\text {th }}$ Ed. Philadelphia, Churchill Livingstone, 2000.

37.Von Eiff C., Peters G., Heilmann C. Pathogenesis of infections due to coagulase-negative staphylococci. Lancet Infect. Dis., 2002, vol. 2, no. 11, pp. 677-685.

38.Ketlinskii S.A., Simbirtsev A.S. Tsitokiny [Cytokines]. SPb., Foliant, 2008, 549 p. (in Russian)

39.Rogova L.N., Shesternina N.V., Zamechnik T.V., Fastova I.A. Matriksnye metalloproteinazy, ikh rol v fiziologicheskikh i patologicheskikh protsessakh (obzor) [Matrix metalloproteinases, their role in physiological and pathological processes (review)]. Vestnik Novykh Meditsinskikh Tekhnologii, 2011, vol. 18, no. 2, pp. 86-89. (in Russian)

40.Protasov M.V., Smagina L.V., Galibin O.V., Pinaev G.P., Voronkina I.V. Zavisimost aktivnosti mmp v ranevom ekssudate krys ot sostoianiia tkanei rany na nachalnykh etapakh ranevogo protsessa [The dependence of MMP activity in the rats' wound exudate on the wound tissue condition at the initial stages of the wound process]. Tsitologiia, 2008, vol. 50, no. 10, pp. 882-886. (in Russian)

41.Tehranzadeh J., Ter-Oganesyan R.R., Steinbach L.S. Musculoskeletal disorders associated with HIV infection and AIDS. Part I: infectious musculoskeletal conditions. Skeletal Radiology, 2004, vol. 33, no. 5, pp. 249-259. DOI: 10.1007/s00256-004-0764-z.

42.Josse J., Velard F., Gangloff S.C. Staphylococcus aureus vs. Osteoblast: Relationship and Consequences in Osteomyelitis. Front Cell Infect. Microbiol., 2015, vol. 5, pp. 85. DOI: 10.3389/fcimb.2015.00085.

43.Jin T., Lu Y., He Q.X., Wang H., Li B.F., Zhu L.Y., Xu Q.Y. The role of MicroRNA, miR-24, and its Target CHI3L1 in Osteomyelitis Caused by Staphylococcus aureus. J. Cell. Biochem., 2015, vol. 116, no. 12, pp. 2804-2813. DOI: 10.1002/jcb.25225.

44.Claro T., Widaa A., O'Seaghda M., Miajlovic H., Foster T.J., O'Brien F.J., Kerrigan S.W. Staphylococcus aureus protein A binds to osteoblasts and triggers signals that weaken bone in osteomyelitis. PLoS One, 2011, vol. 6, no. 4, pp. e18748. DOI: 10.1371/journal. pone.0018748.

45.Ellington J.K., Reilly S.S., Ramp W.K., Smeltzer M.S., Kellam J.F., Hudson M.C. Mechanisms of Staphyloccus aureus invasion of 
cultured osteoblasts. Microb. Pathog., 1999, vol. 26, no. 6, pp. 317-323. DOI: 10.1006/mpat.1999.0272.

46.Tucker K.A., Reilly S.S., Leslie C.S., Hudson M.C. Intracellular Staphylococcus aureus induces apoptosis in mouse osteoblasts. FEMS Microbiol. Lett., 2000, vol. 186, no. 2, pp. 151-156. DOI: 10.1111/j.1574-6968.2000.tb09096.x.

47.Valour F., Rasigade J.P., Trouillet-Assant S., Gagnaire J., Bouaziz A., Karsenty J., Lacour C., Bes M., Lustig S., Bénet T., Chidiac C., Etienne J., Vandenesch F., Ferry T., Laurent F.; Lyon BJI Study Group. Delta-toxin production deficiency in Staphylococcus aureus: a diagnostic marker of bone and joint infection chronicity linked with osteoblast invasion and biofilm formation. Clin. Microbiol. Infect., 2015, vol. 21, no. 6, pp. 568. e1-11. DOI: 10.1016/j.cmi.2015.01.026.

48.Somayaji S.N., Ritchie S., Sahraei M., Marriott I., Hudson M.C. Staphylococcus aureus induces expression of receptor activator of NF-kappaB ligand and prostaglandin E2 in infected murine osteoblasts. Infect. Immun., 2008, vol. 76, no. 11, pp. 5120-5126. DOI: 10.1128/IAI.00228-08.

49.Johansen J.K., Iburg T.M., Nielsen O.L., Leifsson P.S., Dahl-Petersen K., Koch J., Frees D., Aalbæk B., Heegaard P.M., Jensen H.E. Local osteogenic expression of cyclooxygenase-2 and systemic response in porcine models of osteomyelitis. Prostaglandins Other Lipid Mediat., 2012, vol. 97, no. 3-4, pp. 103-108. DOI: 10.1016/j.prostaglandins.2012.01.002.

50.Kader A., Simm R., Gerstel U., Morr M., Römling U. Hierarchical involvement of various GGDEF domain proteins in rdar morphotype development of Salmonella enterica serovar Typhimurium. Mol. Microbiol., 2006, vol. 60, no. 3, pp. 602-616. DOI: 10.1111/j.1365-2958.2006.05123.x.

51.Thwaites G.E., Gant V. Are bloodstream leukocytes Trojan Horses for the metastasis of Staphylococcus aureus? Nat. Rev. Microbiol., 2011, vol. 9, no. 3, pp. 215-222. DOI: 10.1038/nrmicro2508.

52.Hamza T., Li B. Differential responses of osteoblasts and macrophages upon Staphylococcus aureus infection. BMC Microbiol., 2014, vol. 14, pp. 207. DOI: 10.1186/s12866-014-0207-5.

53.Aparna M.S., Yadav S. Biofilms: microbes and disease. Braz. J. Infect. Dis., 2008, vol. 12, no. 6, pp. 526-530.

54.Costerton J.W., Stewart P.S., Greenberg E.P. Bacterial biofilms: a common cause of persistent infections. Science, 1999, vol. 284, no. 5418, pp. 1318-1322. DOI: 10.1126/science.284.5418.1318.

55.Mataraci E., Dosler S. In vitro activities of antibiotics and antimicrobial cationic peptides alone and in combination against methicillin-resistant Staphylococcus aureus biofilms. Antimicrob. Agents Chemother., 2012, vol. 56, no. 12, pp. 6366-6371. DOI: 10.1128/AAC.01180-12.

56.Jacqueline C., Caillon J. Impact of microbial biofilm on the treatment of prosthetic joint infections. J. Antimicrob. Chemother., 2014, vol. 69, no. Suppl. 1, pp. i37-40. DOI: $10.1093 / \mathrm{jac} / \mathrm{dku} 254$.

57.Stewart P.S., Davison W.M., Steenbergen J.N. Daptomycin rapidly penetrates a Staphylococcus epidermidis biofilm. Antimicrob. Agents Chemother., 2009, vol. 53, no. 8, pp. 3505-3507. DOI: 10.1128/AAC.01728-08.

58.Darouiche R.O., Dhir A., Miller A.J., Landon G.C., Raad I.I., Musher D.M. Vancomycin penetration into biofilm covering infected prostheses and effect on bacteria. J. Infect. Dis., 1994, vol. 170, no. 3, pp. 720-723. DOI: 10.1093/infdis/170.3.720.

59.Zheng Z., Stewart P.S. Penetration of rifampin through Staphylococcus epidermidis biofilms. Antimicrob. Agents Chemother., 2002, vol. 46, no. 3, pp. 909-903. DOI: 10.1128/aac.46.3.900-903.2002.

60.Parra-Ruiz J., Vidaillac C., Rose W.E., Rybak M.J. Activities of high-dose daptomycin, vancomycin, and moxifloxacin alone or in combination with clarithromycin or rifampin in a novel in vitro model of Staphylococcus aureus biofilm. Antimicrob. Agents Chemother., 2010, vol. 54, no. 10, pp. 4329-4334. DOI: 10.1128/AAC.00455-10.

61.Gander S., Kinnaird A., Finch R. Telavancin: in vitro activity against staphylococci in a biofilm model. J. Antimicrob. Chemother., 2005, vol. 56, no. 2, pp. 337-343. DOI: 10.1093/jac/dki198.

62.Euba G., Rouse M.S., del Pozo J.L. Linezolid treatment of staphylococcus aureus experimental foreign body osteomyelitis. Abstracts of the $49^{\text {th }}$ Annual ICAAC Meeting. San-Francisco, 2009, abstract B-1322.

63.Saleh-Mghir A., Müller-Serieys C., Dinh A., Massias L., Crémieux A.C. Adjunctive rifampin is crucial to optimizing daptomycin efficacy against rabbit prosthetic joint infection due to methicillin-resistant Staphylococcus aureus. Antimicrob. Agents Chemother., 2011, vol. 55, no. 10, pp. 4589-4593. DOI: 10.1128/AAC.00675-11.

64.Pace J.L., Rupp M.E., Finch R.G. Biofilms, infection, and antimicrobial therapy. London, Boca Raton, Fla, Taylor \& Francis, 2006.

65.Möker N., Dean C.R., Tao J. Pseudomonas aeruginosa increases formation of multidrug-tolerant persister cells in response to quorum-sensing signaling molecules. J. Bacteriol., 2010, vol. 192, no. 7, pp. 1946-1955. DOI: 10.1128/JB.01231-09.

66.Gostev V.V., Sidorenko S.V. Bakterialnye bioplenki i infektsii [Bacterial biofilms and infections]. Zhurnal Infektologii, 2010 , vol. 2, no. 3, pp. 4-15. (in Russian)

Received: 26.12.2018

\section{Information about the authors}

1. Sergei P. Mironov, M.D., Ph.D., Professor, Academician of RAS,

National Medical Research Center Of Traumatology And Orthopedics n.a. N.N. Priorov, Moscow, Russian Federation

2. Archil V. Tsiskarashvili, M.D., Ph.D.,

National Medical Research Center Of Traumatology And Orthopedics n.a. N.N. Priorov, Moscow, Russian

Federation,

Email: armed05@mail.ru

3. Dmitrii S. Gorbatiuk,

National Medical Research Center Of Traumatology And Orthopedics n.a. N.N. Priorov, Moscow, Russian Federation 